\title{
Pengaruh Leverage, Financial Distress dan Profitabilitas terhadap Konservatisme Akuntansi pada Perusahaan Pertambangan di Indonesia Tahun 2013-2017
}

\author{
The Effect of Leverage, Financial Distress and Profitability on Accounting \\ Convertism in Mining Companies in Indonesia 2013-2017
}

\author{
Muhammad Affan Abdurrahman ${ }^{1 *}$, Wita Juwita Ermawati ${ }^{1}$ \\ 1) Departemen Manajemen, Fakultas Ekonomi dan Manajemen, IPB Kampus Dramaga Bogor 16680
}

\begin{abstract}
Accounting conservatism is a precautionary principle in reporting financial statements. This principle slows down the recognition of income and accelerates the recognition of costs, resulting in low profits and assets, and high costs and debt. This study aims to analyzing the effect of leverage, financial distress and profitability as independent variable to accounting conservatism in mining companies as dependent variable. The sample of this study used 20 listed companies. This research are using secondary data published by the company and BEI. Methods in this study using multiple regression analysis processed with software Eviews 10. The results showed that independent variables together significantly affect the changes in accounting conservatism. Profitability variables have a negative and significant effect on accounting conservatism of mining companies.
\end{abstract}

Keywords: accounting conservatism, financial distress, leverage, mining, profitability.

\begin{abstract}
ABSTRAK
Konservatisme akuntansi adalah suatu prinsip kehati-hatian dalam pelaporan laporan keuangan. Prinsip ini memperlambat pengakuan pendapatan dan mempercepat pengakuan biaya, sehingga menghasilkan laba dan aset cenderung rendah, serta biaya dan hutang cenderung tinggi. Tujuan dari penelitian ini adalah untuk menganalisis pengaruh leverage, financial distress dan profitabilitas terhadap konservatisme akuntansi pada perusahaan pertambangan di Indonesia tahun 2013-2017. Data penelitian ini adalah laporan keuangan dari 20 sampel perusahaan pertambangan yang terdaftar di Bursa Efek Indonesia. Metode analisis yang digunakan adalah analisis linear berganda data panel menggunakan program Eviews 10. Hasil pengujian menunjukkan bahwa secara parsial menunjukkan bahwa leverage dan financial distress tidak berpengaruh terhadap konservatisme akuntansi. Variabel profitabilitas berpengaruh negatif signifikan terhadap konservatisme akuntansi perusahaan sektor pertambangan.
\end{abstract}

Kata kunci: financial distress, konservatisme akuntansi, leverage, pertambangan, profitabilitas. 


\section{PENDAHULUAN}

Salah satu bentuk pertanggungjawaban pihak manajerial dalam pengelolaan perusahaan adalah pelaporan dalam bentuk laporan keuangan. Laporan keuangan menjadi cerminan akan baik atau buruknya kinerja perusahaan. Hal ini menjadi penilaian bagi pihak berkepentingan, baik pihak internal maupun eksternal perusahaan. Pihak internal mengharapkan bonus dari kinerja yang baik, investor menginginkan imbal hasil yang tinggi serta pemerintah akan mengenakan pajak yang besar dari sebuah perusahaan yang berkinerja baik. Laporan keuangan yang dibuat perusahaan harus mengacu pada Pernyataan Standar Akuntansi Keuangan (PSAK) yang telah dibuat oleh Dewan Standar Akuntansi Keuangan (DSAK). PSAK memberikan fleksibilitas bagi manajemen dalam menentukan metode maupun estimasi akuntansi yang dapat digunakan dalam menyusun laporan keuangan. Hal ini dapat dilihat pada PSAK 14 tentang Persediaan, PSAK 16 tentang Aset Tetap dan PSAK 19 tentang Aset Tak Berwujud.

Fleksibilitas dalam SAK dapat dimanfaatkan oleh pihak manajerial dalam pencatatan akuntansi dan pelaporannya. Pihak manajerial dapat memilih alternatif metode ataupun estimasi pencatatan sesuai kondisi dan keadaan perusahaan. Manajer yang akan meminjam kredit kepada bank akan cenderung memilih metode atau estimasi yang meningkatkan laba, dan manajer yang berorientasi pada bonus yang tinggi juga akan menaikan labanya. Sebaliknya perusahaan yang sedang menghadapi kondisi ekonomi yang tidak menentu dan harus berhati-hati dalam menyajikan laporan keuangan cenderung memilih akuntansi konservatif. Konservatisme akuntansi adalah pedoman akuntansi yang mengecilkan arti aktiva dan pendapatan, namun membesarkan arti kewajiban dan beban. Beban harus diakui lebih dahulu, sedangkan pendapatan harus diakui terjadi kemudian. Jadi, laba bersih akan di dapat dalam informasi yang lebih rendah. Konservatisme beranggapan bahwa dalam pelaporan keuangan harus lebih pesimis (dikecilkan) daripada optimis (dibesarkan) (Siegel dan Shim 2010). Prinsip ini cocok digunakan pada perusahaan dalam keadaan keuangan yang sulit dan ketidakpastian usaha yang tinggi, karena dapat mengurangi risiko perusahaan bangkrut.

Sektor pertambangan merupakan salah satu sektor yang memiliki ketidakpastian tinggi. Sektor ini juga wajib menyajikan laporan keuangan yang menggunakan prinsip SAK, mengikuti aturan dari Bursa Efek Indonesia (BEI). Menurut Abibraya (2017), pada dasarnya karakteristik industri pertambangan di Indonesia secara umum dapat dilihat dari tiga hal, yaitu: kesempatan, tantangan dan volatility (fluktuasi). Ketiganya sangat mempengaruhi kondisi pertambangan Indonesia, namun secara umum karakteristik industri tambang adalah:

1. Industri dengan padat modal dengan durasi proyek yang lama, sebaran bahan galian terpencar, sehingga hal ini memiliki risiko operasi yang besar.

2. Sensitif terhadap siklus bisnis serta bahan galian bersifat deplesi dan tidak dapat diperbaharui.

3. Pendapatan didorong oleh fluktuasi harga komoditas dan nilai tukar.

4. Biaya yang tinggi dimulai dari biaya eksplorasi, biaya operasional (bahan bakar, konstruksi tambang dan biaya perawatan) sampai biaya untuk menjaga kelestarian lingkungan (air, polusi udara, limbah dan hewan-hewan).

Investasi proyek tambang selain membutuhkan modal yang besar, umumnya juga merupakan proyek dengan jangka panjang, sehingga membutuhkan waktu yang lama untuk pengembalian modal. Bilamana tidak dilakukan pengelolaan proyek yang baik, maka dapat terjadi kebangkrutan. Pernyataan di atas didukung oleh data pada Tabel 1 bahwa selama periode 20132017 terdapat perusahaan tambang yang menghadapi masalah. 
Tabel 1. Daftar perusahaan tambang yang bermasalah periode 2013-2017

\begin{tabular}{lcc}
\hline \multicolumn{1}{c}{ Nama Perusahaan } & Keterangan & Tahun \\
\hline PT Dayaindo Resources International Tbk (KARK) & Pailit & 2013 \\
PT Daya Mandiri Resources Indonesia (DMRI) & Pailit & 2013 \\
& Delisting paksa & \\
PT Asia Natural Resources Tbk (ASIA). & (forced delisting) & 2014 \\
PT Borneo Lumbung Energi \& Metal Tbk (BORN) & Suspend & 2015 - sekarang \\
PT Berau Coal Energy Tbk (BRAU) & Delisting & 2017 \\
PT Permata Prima Sakti Tbk (TKGA) & Delisting & 2017 \\
Petroselat Ltd anak usaha PT Sugih Energy Tbk (SUGI) & Pailit & 2017 \\
\hline
\end{tabular}

Sumber: OJK dan BEI data diolah (2018)

Berdasarkan karakteristik perusahaan sektor pertambangan, diduga terdapat hubungan antara konservatisme akuntansi dengan perusahaan sektor pertambangan, yaitu kegiatan yang mempunyai ketidakpastian yang tinggi. Walaupun kegiatan dalam perusahaan pertambangan sudah dipersiapkan secara cermat, dengan biaya yang besar, tidak ada jaminan bahwa kegiatan pertambangan tersebut menghasilkan keuntungan.

Salah satu faktor dalam konservatisme akuntansi adalah leverage. Leverage merupakan rasio yang menunjukkan seberapa besar hutang digunakan untuk membiayai aktiva perusahaan, karena perusahaan tambang membutuhkan modal yang sangat besar dan didapat dari pinjaman pihak lain. Terdapat Peraturan Menteri Keuangan (PMK) No 169/PMK.010/2015 tentang penentuan besarnya perbandingan antara hutang dan modal perusahaan untuk keperluan penghitungan Pajak Penghasilan ( $\mathrm{PPh})$. Besarnya perbandingan antara hutang dan modal ditetapkan paling tinggi sebesar empat dibanding satu (4:1), tetapi dalam peraturan ini dikecualikan pada Wajib Pajak (WP) usaha pertambangan. Dengan demikian usaha pertambangan dimungkinkan mempunyai perbandingan antara hutang dan modal sendiri lebih dari empat dibanding satu (4:1).

Tingkat leverage yang semakin tinggi menyebabkan semakin besar kemungkinan perusahaan akan melanggar perjanjian kredit. Hal ini terjadi karena pihak manajemen ingin menghindari kovenan hutang dari pihak kreditur. Dengan demikian perusahaan akan berusaha melaporkan laba sekarang lebih tinggi yang dapat dilakukan dengan cara mengurangi biaya-biaya yang ada. Untuk perusahaan tambang, Non Performing Loan (NPL)-nya merupakan yang tertinggi dari sektor lainnya yaitu sebesar 8,12 persen atau naik 1,7 persen dari periode yang sama tahun sebelumnya (Otoritas Jasa Keuangan, September 2017). Hal ini menjadi sinyal bagi investor untuk berhati-hati dalam berinvestasi pada perusahaan pertambangan.

Konservatisme merupakan prinsip kehati-hatian, maka dengan adanya kesulitan keuangan (financial distress) tentu perusahaan akan lebih berhati-hati lagi dalam menghadapi lingkungan bisnis yang tidak pasti. Dengan demikian, tingkat kesulitan keuangan perusahaan yang semakin tinggi akan mendorong manajer untuk menaikkan tingkat konservatisme akuntansi, dan sebaliknya jika tingkat kesulitan keuangan rendah manajer akan menurunkan tingkat konservatisme akuntansi.

Terkait dengan profitabilitas, menurut Lasdi (2008) terdapat hubungan antara profitabilitas dan konservatisme akuntansi yang dapat dikaitkan dengan adanya aspek biaya politis. Khususnya di perusahaan pertambangan yang memiliki profitabilitas tinggi sehingga akan ada aspek biaya politis yang tinggi seperti pajak yang besar. Hal ini menyebabkan perusahaan pertambangan dengan profitabilitas tinggi lebih memilih menerapkan akuntansi yang konservatif dalam rangka mengurangi biaya politis tersebut. Hasil tersebut berbeda dengan penelitian Wardhani (2008) yang menyebutkan bahwa perusahaan besar dan perusahaan yang mengalami pertumbuhan yang baik akan cenderung menggunakan prinsip akuntansi yang kurang konservatif (lebih agresif) dengan menggunakan media akrual untuk meningkatkan profitabilitasnya.

Hasil empiris lain yang dilakukan sebelumnya juga menunjukkan adanya perbedaan. Alfian dan Sabeni (2013), Utama (2012), serta Dewi dan Suryanawa (2014) menyatakan bahwa leverage berpengaruh positif signifikan terhadap konservatisme akuntansi. Namun hasil yang berbeda ditunjukkan oleh Jesica et al. (2012) yang menyatakan bahwa leverage tidak berpengaruh 
terhadap konservatisme akuntansi. Untuk pengaruh financial distress, Firmasari (2016) menyebutkan bahwa financial distress berpengaruh negatif signifikan terhadap konservatisme akuntansi. Hasil tersebut berbeda dengan yang ditemukan oleh Setyaningsih (2008) dan Jesica et al. (2012) bahwa financial distress berpengaruh positif terhadap konservatisme akuntansi Untuk variabel profitabilitas, beberapa penelitian menunjukkan bahwa profitabilitas berpengaruh negatif signifikan terhadap konservatisme akuntansi, yaitu Pramana (2010) dan Yuliarti (2017), namun tidak demikian halnya dengan Wardhani (2008).

Dari pemaparan di atas maka dapat dinyatakan bahwa prinsip konservatisme dapat diterapkan dalam usaha pertambangan yaitu prinsip kehati-hatian dalam usaha yang penuh ketidakpastian. Terdapat beberapa faktor yang diduga dapat memengaruhi konservatisme yaitu leverage, financial distress dan profitabilitas. Namun demikian bagaimana pengaruh variabelvariabel tersebut terhadap konservatisme akuntansi masih belum konsisten. Oleh karena itu tujuan dilakukannya penelitian ini adalah untuk menganalisis 1) pengaruh tingkat hutang (leverage) terhadap konservatisme akuntansi di perusahaan pertambangan; 2) pengaruh kesulitan ekonomi (financial distress) terhadap konservatisme akuntansi di perusahaan pertambangan; dan 3) pengaruh profitabilitas terhadap konservatisme akuntansi di perusahaan pertambangan.

\section{METODE PENELITIAN}

Variabel dependen dalam penelitian ini adalah konservatisme akuntansi yang diukur dengan menggunakan akrual, yaitu selisih antara laba bersih sebelum depresiasi/amortisasi dari kegiatan operasional dengan arus kas operasional. Variabel independen yang digunakan adalah leverage, financial distress, dan profitabilitas. Ukuran leverage yaitu menggunakan rasio hutang terhadap aktiva. Financial distress menggunakan analisis Z-score dengan pengukuran empat variabel yaitu rasio working capital terhadap total aset, rasio retained earning terhadap total aset, rasio EBIT terhadap total asset, dan rasio market value of equity terhadap book value of debt. Sedangkan untuk ukuran profitabilitas menggunakan return on equity (ROE) dan return on asset (ROA). Kerangka pemikiran penelitian dapat dilihat pada Gambar 1.

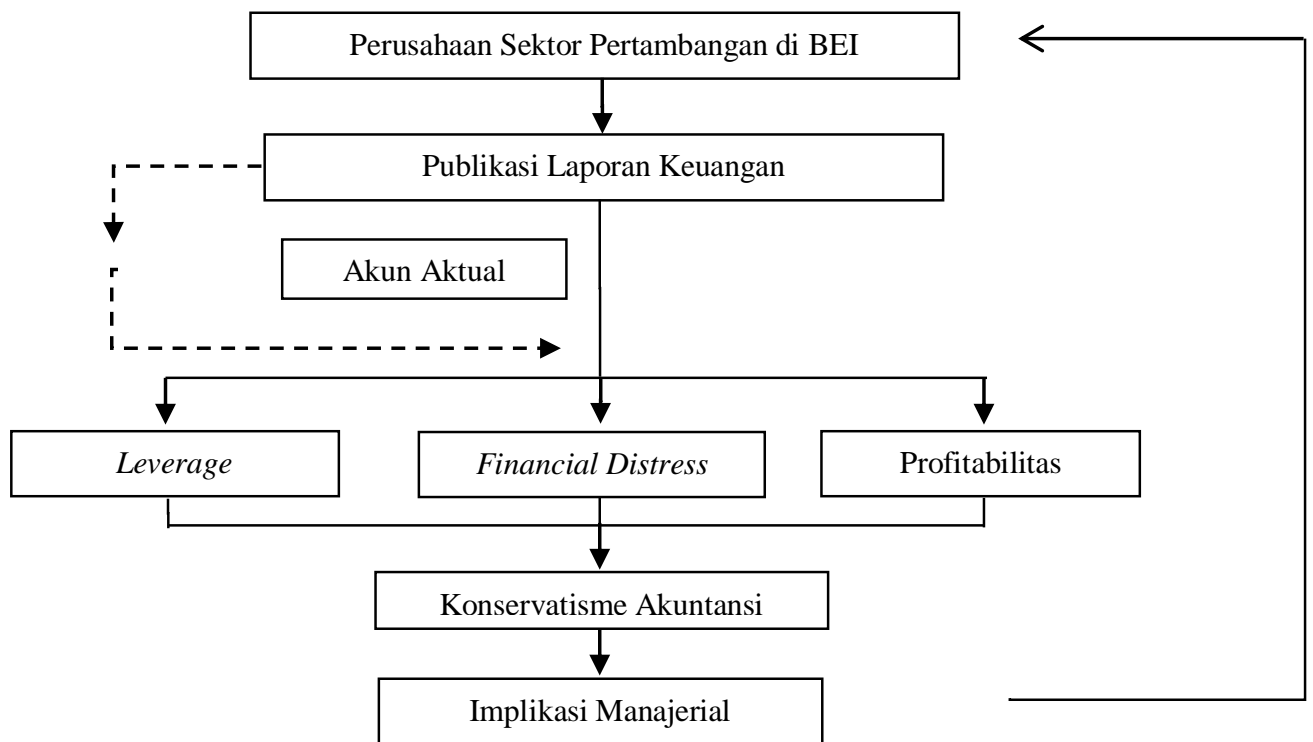

Keterangan: penelitian ini berfokus pada akun aktual

Gambar 1. Kerangka Pemikiran

Hipotesis penelitian yang digunakan adalah sebagai berikut:

H1: Leverage berpengaruh positif terhadap konservatisme akuntansi

H2: Financial distress berpengaruh positif terhadap konservatisme akuntansi

H3: ROE berpengaruh negatif terhadap konservatisme akuntansi

H4: ROA berpengaruh negatif terhadap konservatisme akuntansi 


\section{HASIL DAN PEMBAHASAN}

\section{Gambaran Umum Perusahaan}

Objek dalam penelitian ini adalah perusahaan yang termasuk dalam kelompok indeks sektor pertambangan yang terdaftar di Bursa Efek Indonesia dari tahun 2013 sampai dengan 2017. Perusahaan-perusahaan yang mengalami delisting, suspend dan perusahaan yang baru melakukan Initial Public Offering (IPO) tidak termasuk ke dalam penelitian ini. Total perusahaan yang terdaftar sampai bulan April 2018 yaitu 42 perusahaan (tercatat). Dari 42 perusahaan tersebut diperoleh 35 perusahaan yang memenuhi kriteria sebagai objek penelitian. Sebanyak 35 perusahaan tambang dieliminasi kembali menggunakan software SPSS dengan melakukan pengujian outlier untuk mengeliminasi data-data pencilan maka dihasilkan menjadi 20 perusahaan tambang.

\section{Uji Multikolinieritas}

Uji multikolinieritas digunakan untuk menguji variabel independen apakah saling berkorelasi antar variabel independen. Apabila hal ini terjadi maka akan mengganggu ketepatan dari model yang dibuat. Oleh karena itu, untuk membuat model regresi berganda yang baik yaitu variabel independen memiliki hubungan dengan variabel dependen, namun tidak saling berhubungan antar variabel bebas (Nachrowi dan Usman 2006). Uji multikolinieritas antar variabel bebas dapat diketahui dengan tidak adanya multikolinieritas jika antar variabel koefisien korelasi bernilai lebih dari 0,8 . Variabel bebas yang akan diuji pada penelitian ini yaitu leverage $\left(\mathrm{X}_{1}\right)$, financial distress $\left(\mathrm{X}_{2}\right)$, return on equity $\left(\mathrm{X}_{3}\right)$, return on asset $\left(\mathrm{X}_{4}\right)$. Hasil uji ini dapat dilihat pada Tabel 2.

Tabel 2. Output Uji Multikolineritas

\begin{tabular}{lrrrr}
\hline & LEV & FINDIS & ROE & ROA \\
\hline LEV $\left(\mathrm{X}_{1}\right)$ & 1,000 & $-0,748$ & 0,314 & $-0,266$ \\
FINDIS $\left(\mathrm{X}_{2}\right)$ & $-0,748$ & 1,000 & $-0,430$ & 0,457 \\
ROE $\left(\mathrm{X}_{3}\right)$ & 0,314 & $-0,430$ & 1,000 & $-0,494$ \\
ROA $\left(\mathrm{X}_{4}\right)$ & $-0,266$ & 0,457 & $-0,494$ & 1,000 \\
\hline
\end{tabular}

Sumber: Data olahan (2018)

Berdasarkan tabel di atas diketahui bahwa tidak terdapat multikolinieritas antar variabel bebas. Hal ini dikarenakan nilai koefisien korelasi yang dihasilkan tidak ada yang memiliki nilai lebih dari 0,8 . Sehingga variabel bebas yang digunakan dalam penelitian ini memenuhi uji asumsi klasik yaitu uji multikolinieritas karena tidak terdapat variabel yang saling berkorelasi.

\section{Uji Autokorelasi}

Uji autokorelasi dilakukan untuk menguji untuk menunjukkan sifat yang tidak bebas residual regresi dari satu observasi ke observasi lainnya. Pengujian autokorelasi dapat dicari dari tabel Durbin Watson berdasarkan K (jumlah variabel bebas) dan n (jumlah sampel) yang relevan. Statistic DW adalah suatu prosedur rutin yang umum ditemukan pada banyak software statistik, sehingga yang dilakukan adalah melihat apakah nilai dimaksud terletak di antara $2<\mathrm{DW}<4$-Du untuk menentukan ada tidaknya autokorelasi (Ariefianto 2012).

Tabel 3. Output Uji Autokorelasi

\begin{tabular}{llll}
$R$-squared & 0,570 & Mean dependent var & 0,118 \\
Adjusted $R$-squared & 0,440 & S.D. dependent var & 0,093 \\
S.E. of regression & 0,043 & Sum squared resid & 0,144 \\
F-statistic & 4,382 & Durbin-Watson stat & $\mathbf{2 , 1 4 3}$ \\
Prob(F-statistic) & 0,000 & & \\
\hline
\end{tabular}

Sumber: Data olahan (2018)

Hasil dari tabel tersebut diketahui bahwa nilai dari Durbin-Watson sebesar 2,143. Nilai statisktik D yang harus dipenuhi agar tidak terdapat autokorelasi adalah $\mathrm{d}_{\mathrm{u}} \leq \mathrm{d} \leq 4-\mathrm{d}_{\mathrm{u}}$. Maka diperoleh hasil bahwa $1,592 \leq 2,143 \leq 2,408$, sehingga $\mathrm{H}_{0}$ diterima pada penelitian ini yaitu tidak terdapat masalah asumsi klasik yaitu tidak ada autokorelasi. 


\section{Uji Heteroskedastisitas}

Uji heteroskedastisitas yang digunakan pada penelitian ini adalah uji glesjer. Pengujian dilakukan antara masing-masing variabel bebas. Jika nilai prob. > 0,05 maka dapat disimpulkan bahwa variabel tidak memiliki masalah heteroskedastisitas atau bisa disebut homoskedastisitas. Hasil pengujian gelsjer dilihat dalam Tabel 4 berikut:

Tabel 4. Output Uji Heteroskedastisitas dengan Uji Glesjer

\begin{tabular}{ccccc}
\hline Variable & Coefficient & Std. Error & t-Statistic & Prob. \\
\hline KONS (Y) & 0,032 & 0,022 & 1,464 & 0,147 \\
LEV (X1) & 0,016 & 0,033 & 0,496 & 0,622 \\
FINDIS (X2) & 0,000 & 0,002 & 0,083 & 0,934 \\
ROE (X3) & $-0,041$ & 0,030 & $-1,370$ & 0,174 \\
ROA (X4) & 0,001 & 0,047 & 0,023 & 0,982 \\
\hline
\end{tabular}

Sumber: Data olahan (2018)

Pada Tabel 4 diketahui bahwa seluruh nilai Prob. > 0.05 untuk leverage, financial distress, $R O E, R O A$ dan konservatisme. Hal ini menunjukkan bahwa tidak ada masalah uji asumsi klasik terkait heteroskedastisitas dari seluruh variabel dalam penelitian. Maka dapat disimpulkan bahwa seluruh variabel memenuhi asumsi homoskedastisitas.

\section{Uji $\mathbf{R}^{2}$ (Uji Koefisien Determinasi)}

Uji koefisien determinasi $\left(\mathrm{R}^{2}\right)$ adalah menentukan proporsi atau prosentase total variasi dalam variabel bebas yang dijelaskan oleh variabel independen. Bertujuan untuk mengetahui seberapa besar variabel dependen mampu dijelaskan secara bersama-sama dengan variabel independen. Hasil uji koefisien determinasi dari penelitian ini dapat dilihat pada Tabel 5.

Tabel 5. Output Uji R ${ }^{2}$ (Koefisien Determinasi)

$\begin{array}{llll}R \text {-squared } & \mathbf{0 , 5 7 0} & \text { Mean dependent var } & 0,118 \\ \text { Adjusted R-squared } & \mathbf{0 , 4 4 0} & \text { S.D. dependent var } & 0,093 \\ \text { S.E. } \text { of regression } & 0,044 & \text { Sum squared resid } & 0,144 \\ \text { F-statistic } & 4,382 & \text { Durbin-Watson stat } & 2,143 \\ \text { Prob }(F \text {-statistic }) & 0,000 & & \end{array}$

Sumber: Data olahan (2018)

Hasil uji $\mathrm{R}^{2}$ menunjukkan angka 0.44 , hal ini menunjukkan bahwa dengan fixed effect model sebesar 44 persen dari variasi yang terjadi pada variabel dependen (konservatisme) dapat dijelaskan oleh variabel bebasnya (LEV, FINDIS, ROE dan ROA).

\section{Uji F (Uji Model secara keseluruhan)}

Uji F dilakukan untuk mengetahui apakah terdapat pengaruh secara bersama-sama yang signifikan pada variabel dependen terhadap variabel independen (Ghozali 2009). Hasil uji F dari penelitian ini dapat dilihat pada Tabel 6 .

Tabel 6. Output Uji F

\begin{tabular}{llll}
\hline$R$-squared & 0,570 & Mean dependent var & 0,118 \\
Adjusted $R$-squared & 0,440 & S.D. dependent var & 0,093 \\
S.E. of regression & 0,044 & Sum squared resid & 0,144 \\
F-statistic & 4,382 & Durbin-Watson stat & 2,143 \\
Prob $(F$-statistic $)$ & $\mathbf{0 , 0 0 0}$ & & \\
\hline
\end{tabular}

Sumber: Data olahan (2018)

Berdasarkan uji tersebut diketahui bahwa nilai Prob (F-Statistic) memiliki nilai $<0,05$ maka $\mathrm{H}_{\mathrm{a}}$ diterima. Hal ini menunjukkan bahwa secara keseluruhan variabel yang digunakan dalam penelitian (LEV, FINDIS, ROE dan ROA) berpengaruh secara signifikan terhadap konservatisme akuntansi.

\section{Hasil Persamaan Regresi Linier Berganda (Uji T)}

Analisis dari persamaan Regresi Linier Berganda yang digunakan dalam penelitian adalah untuk mengetahui seberapa besar pengaruh variabel leverage $\left(\mathrm{X}_{1}\right)$, financial distress $\left(\mathrm{X}_{2}\right)$, return 
on equity $\left(\mathrm{X}_{3}\right)$, return on asset $\left(\mathrm{X}_{4}\right)$ terhadap konservatisme akuntansi $(\mathrm{Y})$ sebagai variabel dependen dalam penelitian. Hasil uji Chow dan Hausman menunjukkan bahwa model regresi terbaik yang dapat digunakan dalam penelitian ini adalah fixed effect model. Hasil pengujian regresi linier berganda dapat dilihat pada Tabel 7. Dari Tabel 7 diketahui bahwa persamaan regresi yang dihasilkan dapat dirumuskan sebagai berikut.

$$
\Upsilon=0.179-0.068 X 1-0.002 X 2-0.175 X 3-0.177 X 4
$$

Tabel 7. Output Uji T

\begin{tabular}{cccccc}
\hline Variable & Coefficient & probabilitas & Output Sign & signifikansi & Keputusan \\
\hline Leverage $(\mathrm{X} 1)$ & $-0,068$ & 0,118 & Negatif & Tidak & $\mathrm{H}_{0}$ diterima \\
Findis $(\mathrm{X} 2)$ & $-0,002$ & 0,545 & Negatif & Tidak & $\mathrm{H}_{0}$ diterima \\
ROE $(\mathrm{X} 3)$ & $-0,175$ & 0,000 & Negatif & Ya & $\mathrm{H}_{0}$ ditolak \\
ROA $(\mathrm{X} 4)$ & $-0,177$ & 0,000 & Negatif & Ya & $\mathrm{H}_{0}$ ditolak \\
\hline
\end{tabular}

Sumber: Data olahan (2018)

\section{Pengaruh Leverage terhadap Konservatisme Akuntansi}

Hipotesis yang pertama adalah leverage berpengaruh positif terhadap konservatisme akuntansi. Leverage memiliki nilai koefisien -0,068 dengan nilai probabilitas 0,118 lebih dari 0,05 maka hipotesis $\mathrm{H}_{0}$ diterima. $\mathrm{Hal}$ ini menunjukkan bahwa leverage tidak memiliki pengaruh yang signifikan terhadap konservatisme akuntansi. Hasil penelitian bahwa leverage tidak berpengaruh terhadap tingkat konservatisme akuntansi sejalan dengan penelitian Jesica at al. (2012) dan berlawanan dengan hipotesis penelitian. Hal ini diduga karena dengan prinsip konservatisme yang merupakan sikap kehati-hatian dalam menghadapi lingkungan yang tidak pasti maka perusahaan akan selalu menggunakan prinsip ini tidak peduli apakah kewajibannya tinggi atau rendah. Dapat dilihat pada analisis deskriptif bahwa 45 persen aktiva perusahaan tambang dibiayai dari hutang, dengan hutang yang besar tersebut maka perusahaan tambang sudah semestinya menerapkan prinsip konservatisme akuntansi dalam pelaporan keuangannya. Dengan demikian investor maupun kreditur tidak perlu ragu ketika menginvestasikan dananya pada sektor pertambangan. Rasio hutang pada penelitian ini tidak signifikan sehingga kurang tepat digunakan sebagai alat analisis untuk menentukan faktor konservatisme di perusahaan pertambangan.

\section{Pengaruh Financial Distress terhadap Konservatisme Akuntansi}

Hipotesis yang kedua adalah financial distress berpengaruh positif terhadap konservatisme akuntansi. Financial distress memiliki nilai koefisien -0,002 dengan nilai probabilitas 0,544 lebih dari 0,05 maka hipotesis $\mathrm{H}_{0}$ diterima. Financial distress tidak memiliki pengaruh dikarenakan setiap tahunnya perusahaan tambang berusaha meningkatkan kondisi keuangan menjadi sehat atau tidak bangkrut. Pihak manajemen berusaha memperbaiki kinerjanya setelah melewati kondisi keuangan yang sulit pada tahun 2013-2015. Dengan kondisi kesulitan ekonomi yang semakin kecil maka pihak manajemen juga berusaha mengurangi konservatisme akuntansi, ini bisa dilihat pada arah konservatisme yang negatif (walaupun tidak signifkan). Hasil ini tidak sejalan dengan apa yang dikemukakan oleh Firmasari (2016), Setyaningsih (2008) dan Jesica et al. (2012) yang menyatakan bahwa financial distress berpengaruh terhadap konservatisme akuntansi.

Prinsip konservatisme sangat tepat digunakan pada perusahaan yang sedang mengalami kesulitan keuangan, tetapi menjadi bias ketika diterapkan pada perusahaan yang sedang tumbuh atau sedang meningkatkan kinerjanya. Perusahaan yang sedang tumbuh atau mengejar laba yang tinggi biasanya menggunakan akuntansi yang agresif. Financial distress pada penelitian ini tidak signifikan sehingga kurang tepat digunakan sebagai alat analisis untuk menentukan faktor konservatisme di perusahaan pertambangan.

\section{Pengaruh Return on Equity terhadap Konservatisme Akuntansi}

Hipotesis yang ketiga adalah $R O E$ berpengaruh negatif terhadap konservatisme akuntansi. ROE memiliki nilai koefisien $-0,175$ dengan nilai probabilitas 0,000 kurang dari 0,05 maka 
hipotesis $\mathrm{H}_{0}$ ditolak. Hal ini menunjukkan bahwa $R O E$ memiliki pengaruh negatif yang signifikan terhadap konservatisme akuntansi. Penurunan $R O E$ sebesar satu satuan akan meningkatkan konservatisme akuntansi sebesar 0,175 satuan. Interpretasinya adalah bahwa pada sektor pertambangan di Indonesia, perusahaan yang memiliki profitabilitas yang tinggi akan menerapkan prinsip-prinsip akuntansi yang kurang konservatif (atau lebih agresif). Hal ini karena perusahaan lebih percaya diri dan menunjukkan pada investor terkait dengan prospek perusahaan di masa depan.

Hasil penelitian ini konsisten dengan penelitian Rohadi (2018) dan Yuliarti (2017) yang menyebutkan bahwa ROE berpengaruh negatif signifikan terhadap konservatisme akuntansi. Rasio ini menunjukkan efisiensi dari penggunaan modal sendiri. Dengan ini menunjukkan bahwa perusahaan pertambangan ingin memberikan sinyal bahwa prospek perusahaan di masa depan adalah positif sehingga ketika laba sedang tinggi maka tidak perlu menaikan prinsip konservatisme, dan juga memperlihatkan penggunaan modal sendiri untuk menghasilkan laba sangat efektif. Didukung juga pada penelitian ini bahwa terjadi kenaikan kapitalisasi pasar sektor pertambangan, pada akhir 2015 nilai kapitalisasi pasar hanya 161 triliun Rupiah, pada tahun 2016 terjadi kenaikan menjadi 198 triliun Rupiah atau naik 23 persen (PWC report 2018), dan terus mengalami kenaikan dikarenakan terjadi tren kenaikan kinerja sektor pertambangan sampai akhir tahun 2017. Selama periode 2016-2017, perusahaan sektor pertambangan mampu menurunkan biaya operasi di tengah meningkatnya volume produksi yang mengakibatkan prinsip konservatismenya berkurang. Rasio profitabilitas dari perhitungan ROE adalah signifikan sehingga dapat digunakan menjadi alat analisis untuk menentukan faktor konservatisme akuntansi.

\section{Pengaruh Return on asset terhadap Konservatisme Akuntansi}

Hipotesis yang keempat adalah $R O A$ berpengaruh negatif terhadap konservatisme akuntansi. $R O A$ memiliki nilai koefisien $-0,177$ dengan nilai probabilitas 0,000 kurang dari 0,05 maka hipotesis $\mathrm{H}_{0}$ ditolak. Hal ini menunjukan bahwa $R O A$ memiliki pengaruh negatif yang signifikan terhadap konservatisme akuntansi. Penurunan ROA sebesar satu satuan akan meningkatkan konservatisme akuntansi sebesar 0,177 satuan.

ROA adalah rasio profitabilitas yang menunjukkan persentase keuntungan yang diperoleh perusahaan sehubungan dengan keseluruhan sumberdaya atau jumlah aset yang dimiliki. ROA dapat membantu manajemen dan investor untuk melihat seberapa baik suatu perusahaan mampu mengkonversi investasinya pada aset menjadi laba. Pada penelitian di perusahaan pertambangan menunjukkan pengaruh yang negatif signifikan terhadap konservatisme. Hal ini memberikan arti bahwa perusahaan petambangan telah memanfaatkan aset yang dimilikinya dengan maksimal untuk menghasilkan laba. Pihak manajemen ingin menunjukkan bahwa dengan mengurangi prinsip konservatisme akuntansi, manajemen sudah mampu mengelola aset tambang yang besar dan relatif mahal menjadi sebuah laba.

Pengaruh profitabilitas dari perhitungan ROA adalah signifikan sehingga dapat digunakan menjadi alat analisis untuk menentukan faktor konservatisme akuntansi. ROA memiliki arah pengaruh yang negatif sesuai dengan hipotesis penelitian, yang artinya ketika perusahaan tambang ingin menunjukkan pemanfaatan aset dengan maksimal maka pihak manajemen mengurangi prinsip konservatisme akuntansi.

\section{Implikasi Manajerial}

Rasio leverage berpengaruh negatif tidak signifikan terhadap konservatisme akuntansi menunjukkan bahwa tanpa memperhatikan tinggi atau rendahnya kewajiban atau hutang kepada kreditur, perusahaan pertambangan tetap menerapkan prinsip konservatisme. Hal ini dilakukan pihak manajerial untuk tetap berhati-hati dalam menjalankan usaha pertambangan terutama menjaga kepercayaan kreditur atas dana yang dipinjamkannya. Merujuk pada Tabel 1 tentang perusahaan tambang yang bermasalah dimana faktor utamanya adalah kegagalan perusahaan dalam melunasi hutangnya, dengan demikian sebaiknya manajemen perusahaan pertambangan tetap menerapkan prinsip konservatisme akuntansi. 
Variabel financial distress berpengaruh negatif tidak signifikan ini menggambarkan bahwa perusahaan pertambangan sudah mulai keluar dari keadaan keuangan yang sulit. Hal ini juga ditunjukkan dengan adanya tren kenaikan laba perusahaan pertambangan tahun 2016-2017. Tahun 2018 menjadi kesempatan perusahaan pertambangan memperbaiki kinerja serta menghasilkan laba sebanyak mungkin dengan mengurangi prinsip konservatisme karena prinsip ini cocok digunakan pada saat kesulitan keuangan. Ketika terjadi tren kenaikan atau pertumbuhan sebaiknya menggunakan prinsip akuntansi yang agresif.

Rasio profitabilitas berpengaruh negatif signifikan sehingga perusahaan tambang lebih baik mencari dana dari modal sendiri dengan mengeluarkan saham daripada mencari dana dari hutang karena mempunyai risiko yang besar. Penelitian ini menunjukan bahwa perusahaan tambang sudah mampu mengelola dana sendiri yang berasal dari penerbitan saham baru untuk menghasilkan laba sehingga prinsip konservatisme sudah berkurang. Konservatisme berkurang karena perusahaan lebih kecil dalam membayarkan beban bunga. Dana tambahan yang diperoleh dapat dimanfaatkan untuk memperbaharui peralatan dan aset perusahaan karena tren produksi yang tinggi harus diikuti dengan aset yang modern.

\section{KESIMPULAN}

Hasil penelitian ini menunjukkan bahwa ketiga variabel (leverage, financial distress dan profitabilitas) secara bersamaan memiliki pengaruh yang signifikan terhadap konservatisme. Namun demikian pengujian secara parsial menunjukkan bahwa variabel leverage dan financial distress tidak berpengaruh terhadap konservatisme akuntansi pada perusahaan pertambangan periode 2013-2017. Variabel yang berpengaruh signifikan adalah variabel profitabilitas yang diukur oleh ROE dan ROA. Rasio profitabilitas dengan arah yang negatif menunjukkan bahwa semakin tinggi laba yang diperoleh maka perusahaan akan mengurangi prinsip konservatisme akuntansi. Hal ini juga didukung dengan adanya tren kenaikan laba pada perusahaan tambang selama dua tahun terakhir setelah mengalami kesulitan keuangan sebelumnya.

\section{DAFTAR PUSTAKA}

Abibraya. (2017). Risiko Bisnis Tambang [Internet]: diunduh [Maret 2018]. https://id.linkedin.com/pulse/prospek-risiko-bisnis-tambang-batubara indonesia-dan 2017abhipraya.

Alfian, \& Sabeni. (2013). Analisis Faktor-faktor yang Berpengaruh Terhadap Pemilihan Konservatisme Akuntansi. Journal of Accounting, 2(3).

Ariefianto, M. D. (2012). Ekonometrika Esensi dan Aplikasi Dengan Menggunakan Eviews. Jakarta: Penerbit Erlangga.

Brigham, E. F, \& Houston, J. F. (2001). Manajemen Keuangan. Jakarta: Erlangga

Dewi, \& Suryanawa. (2014). Pengaruh Struktur Kepemilikan Manajerial, Leverage, dan Financial Distress terhadap Konservatisme Akuntansi. Bali, Indonesia: Universitas Udayana.

Firmasari, D. (2016). Pengaruh Leverage, Ukuran Perusahaan dan Financial Distress terhadap Konservatisme Akuntansi [Skripsi]. Surabaya: Universitas Airlangga Surabaya.

[IAI] Ikatan Akuntansi Indonesia. (2009). Pernyataan Standar Akuntans Keuangan. Jakarta: Salemba Empat.

[IPB] Institut Pertanian Bogor. (2014). Pedoman Penulisan Karya Ilmiah Edisi Ketiga. Bogor: IPB Press.

Jesica et al. (2012). Pengaruh Tingkat Keuangan dan Tingkat Hutang Terhadap Konservatisme Akuntansi Pada Perusahaan Manufaktur di BEI. [Jurnal]. Surabaya: Unika Widya Mandala.

Lasdi, L. (2008). Perilaku Manajemen Laba Perusahaan dan Konservatisma Akuntansi: Berbeda atau Sama?. Jurnal Manajemen Teori dan Terapan. 1(2).

Nachrowi, \& Usman, H. (2006). Pendekatan Populer dan Praktis Ekonometrika Untuk Analisis Ekonomi dan Keuangan. Jakarta: Lembaga Penerbit FE UI. 
Pramana, A. D. (2010). Pengaruh Mekanisme Corporate Governance, Profitabilitas dan Leverage terhadap Konservatisme Akuntansi. Surakarta, Indonesia: Universitas Sebelas Maret.

Price Waterhouse Coopers. (2018). Mine 2018 Temting time. 2018. Indonesia: Report PWC.

[PMK] Peraturan Menteri Keuangan Republik Indonesia Nomor 169/PMK.010/2015 tentang Penentuan Besarnya Perbandingan antara Hutang dan Modal Perusahaan untuk Keperluan Penghitungan Pajak Penghasilan. [Internet]. [Diunduh Juni2018]. Tersedia pada: http://ortax.org.

Rohadi, D. (2018). Pengaruh Mekanisme Good Corporate Governance, Profitabilitas, Leverage dan Ukuran Perusahaan terhadap Konservatisme Akuntansi. Jakarta, Indonesia: UIN Syarif Hidayatullah Jakarta.

Savitri, E. (2016). Konservatisme Akuntansi: Cara Pengukuran, Tinjauan Empiris dan FaktorFaktor yang Mempengaruhi. Yogyakarta: Pustaka Sahila Yogyakarta.

Setyaningsih, H. (2008). Pengaruh Tingkat Kesulitan Keuangan Perusahaan terhadap Konservatisme Akuntansi [Jurnal]. Yogyakarta: Universitas Muhammadiyah Yogyakarta.

Siegel, K. J., \& Shim, J. K. (2010). Kamus Istilah Akuntansi. Jakarta: PT Elex Media Komputindo

Utama, I. Y. (2012). Pengaruh Kepemilikan Manajerial, Leverage, Growth Opportunities dan Ukuran Perusahaan terhadap Konservatisme Akuntansi. Jakarta, Indonesia: UIN Syarif Hidayatullah Jakarta.

[UU] Undang-Undang No 4. 2009. Pertambangan, Mineral dan Batubara. [Internet]. [diunduh Pebruari 2018]. Tersedia pada: http://m.hukumonline.com/pusatdata/detail/28851/node/1060/uu-4-tahun-2009Pertambangan-Mineral-Batubara.

Yuliarti, D. (2017). Pengaruh Leverage, Ukuran Perusahaan, Kepemilikan Manajerial, Ukuran Dewan Komisaris dan Profitabilitas terhadap Konservatisme Akuntansi. Semarang, Indonesia: Universitas Negeri Semarang.

Wardhani, R. (2006). Mekanisme Corporate Governance Dalam Perusahaan Yang Mengalami Permasalahan Keuangan. Simposium Nasional Akuntansi IX. 